\title{
Analysis of Characteristics and Risk Factors of Unintentional Injuries in Children With Cerebral Palsy
}

\section{LiJuan Liang}

Hunan Children's Hospital

KeWei Wang

Hunan Children's Hospital

NanFei Hu

Hunan Children's Hospital

ShuaiZheng Gong

Hunan Children's Hospital

Li Liu

Hunan Children's Hospital

Jun Qiu ( $\nabla$ qiujuntrevor@163.com )

Hunan Children's Hospital

\section{Research Article}

Keywords: children, cerebral palsy, injuries

Posted Date: February 2nd, 2021

DOI: https://doi.org/10.21203/rs.3.rs-146821/v1

License: () (1) This work is licensed under a Creative Commons Attribution 4.0 International License. Read Full License 


\section{Abstract}

In recent years, the incidence of accidental injuries among disabled children increased, including children with cerebral palsy(CP). However, there are few reports on the characteristics and risk factors of unintentional injuries in children with cerebral palsy. Therefore, we collected 117 children with $\mathrm{CP}$ as the research objects, and analyzed the characteristics and influencing factors of unintentional injuries of them to provide effective preventive measures and reduce the incidence of accidental injuries in children with CP. Results reveal that the incidence of once unintentional injuries in children with $\mathrm{CP}$ in the past 3 months was $32.47 \%$, and the incidence of re-injury was $3.4 \%$, which was lower than that of normal or disabled children. In addition, our research also found that the causes of unintentional injuries of children with CP were mainly fall. The injured parts were mainly lower limbs and head and neck. The injuries mainly occured indoors, and most unintentional injuries occurred during when resting, sleeping or relaxing. Multivariate logistic regression analysis of this study found that girls, low family income and less time with their parents were risk factors for unintentional injuries in children with $\mathrm{CP}$.

\section{Introduction}

Unintentional injuries refer to human injuries caused by various accidents, which are purposeless and unconscious injuries, such as drowning, car accidents, animal bites, burns, scalds, falls, poisoning, and medical accidents. Unintentional injuries which not only seriously affect children physical and mental health, but also bring a series of economic and social problems to the family and society, have become one of the most important public health issues in the 21 st century ${ }^{[1-3]}$. Injuries were the leading cause of death for children aged 1-17, which resulted in the deaths of approximately 65,000 children each year. In addition, monitoring data in China in 2014 showed that the death rate of children and adolescents aged 0-17 was 22.90 per 100,000. The main causes of death among Chinese children and adolescents are drowning and road traffic injuries ${ }^{[4]}$. In China, 8.77 out of 100,000 children died from drowning, of which $56.58 \%$ were from 1 to 14 years old ${ }^{[5]}$. Besides, more than 18,500 children under the age of 14 died in road traffic accidents, which was twice that of Europe and 2.6 times that of the United States ${ }^{[6]}$.

Disability is defined as a decline in long-term social skills (such as going to school or entertainment) due to physical or mental reasons. It seriously affected children's growth and development, reduced their school, social and recreational abilities, and brought a huge economic burden to their families and society at the same time ${ }^{[7,8]}$. Cerebral Palsy (CP) is a group of persistent central movement and postural development disorders, and activity limitation syndromes. This syndrome is caused by non-progressive brain damage to the developing fetus or infants ${ }^{[9,10]}$. Children with CP have been treated for a long time, but the children and their families had low awareness of unintentional injuries. Presently, there have been studies on the characteristics and risk factors of accidental injuries of disabled and non-disabled children at home and abroad ${ }^{[6,11]}$. More and more studies have shown that children with disabilities were more likely to be dangerous than children without ${ }^{[12,13]}$. One foreign study has shown that children with CP had a higher risk of accidental injury compared with children without $\mathrm{CP}$. In addition, girls with $\mathrm{CP}$ had the 
highest risk of hospital-treated injury ${ }^{[14]}$. However, the study only described the characteristics of accidental injuries in children with $\mathrm{CP}$, never elaborate on the risk factors of accidental injuries in children with CP. Therefore, this study collected 117 children with CP who were admitted to the Hunan Children's Hospital from January 1, 2018 to March 1, 2019 as the research objects to provide a theoretical basis for the health decisions of disabled children.

\section{Results}

\subsection{The basic information of the 117 study subjects 2.1.1 Features of unintentional injuries of children with $\mathrm{CP}$ in the past three months}

Of the 117 children with CP, 38 (32.5\%) had unintentional injuries in the past 3 months: $33(28.2 \%)$ had one unintentional injury, and $4(3.4 \%)$ had re-injuries. $1(0.9 \%)$ had 3 times accidental injuries. From the point of view of the location and site of injuries, most of them occurred indoors (20/38, 52.6\%) and outdoor courtyards $(8 / 38,21.1 \%)$, and the main injured parts were head and neck $(17 / 38,44.7 \%))$ and lower limbs $(16 / 38,42.1 \%)$; from the point of view of the cause of injury (3 cases of children did not report the cause of injury), accidental fall was the main cause $(22 / 35,62.9 \%)$; In terms of the severity the treatment of injuries, mild-to-moderate injuries $(30 / 35,85.7 \%)$ were the main ones, most of them were handled in hospitals or handled by themselves $(29 / 35,82.9 \%)$, and more than half were hospitalized for treatment $(21 / 35,60 \%)$; Unintentional injuries of children with CP mainly occur in leisure activities such as sleeping and resting $(22 / 35,62.9 \%)$ (Table 1$)$. 
Table 1

Characteristics of unintentional injuries in children with $\mathrm{CP}$ in the past three months and one year Injury characteristics

Past three months

Past year

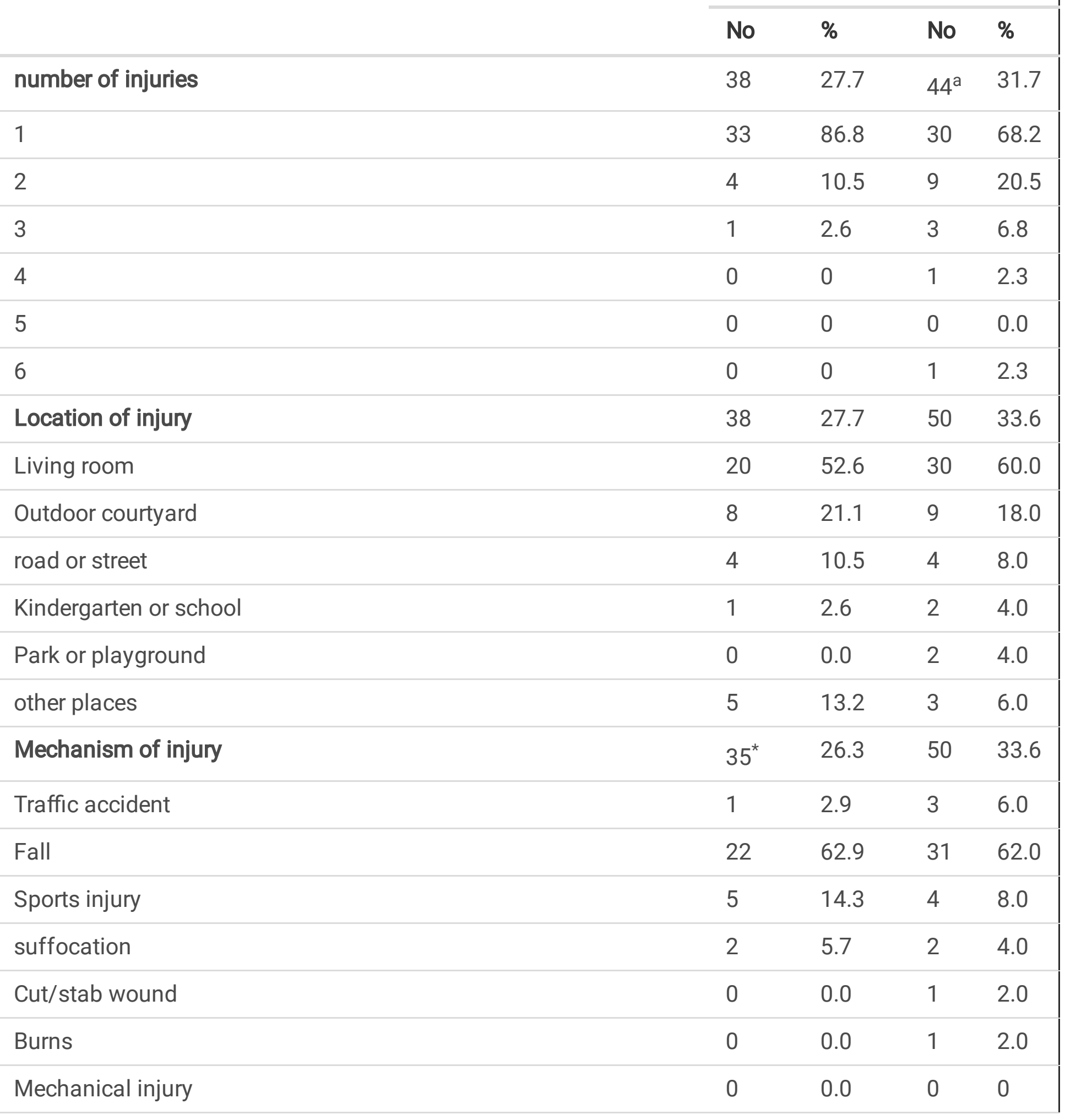

Note *: 3 children with CP did not report relevant information; \#: 5 children with CP did not report relevant information; a: 6 children with $\mathrm{CP}$ did not report relevant information; $\mathrm{b}: 1$ children with $\mathrm{CP}$ did not report relevant information; c:7 children with CP did not report relevant information; $\mathrm{d}$ : 4 children with CP did not report relevant information 


\begin{tabular}{|c|c|c|c|c|}
\hline \multirow[t]{2}{*}{ Injury characteristics } & \multicolumn{2}{|c|}{$\begin{array}{l}\text { Past three } \\
\text { months }\end{array}$} & \multicolumn{2}{|c|}{ Past year } \\
\hline & No & $\%$ & No & $\%$ \\
\hline bite & 1 & 2.9 & 3 & 6.0 \\
\hline collision & 2 & 5.7 & 3 & 6.0 \\
\hline other & 2 & 5.7 & 2 & 4.0 \\
\hline Severity of injury & $35^{*}$ & 26.3 & 50 & 33.6 \\
\hline Minor & 16 & 45.7 & 26 & 52.0 \\
\hline Moderate & 14 & 40.0 & 16 & 32.0 \\
\hline Severe & 5 & 14.3 & 7 & 14.0 \\
\hline Disability & 0 & 0 & 1 & 2.0 \\
\hline Treatment after injury & $35^{*}$ & 26.3 & 50 & 33.6 \\
\hline No processing & 3 & 8.6 & 6 & 12.0 \\
\hline Do it yourself (own or parent) & 9 & 25.7 & 16 & 32.0 \\
\hline Kindergarten or school doctor & 1 & 2.9 & 1 & 2.0 \\
\hline clinic & 2 & 5.7 & 3 & 6.0 \\
\hline Community Health Service Center/Station & 0 & 0 & 0 & 0 \\
\hline Diagnosis and treatment in district-level and above hospitals & 20 & 57.1 & 24 & 48.0 \\
\hline Harm result & $33^{\#}$ & & $47^{\star}$ & 31.8 \\
\hline No discomfort & 4 & 12.1 & 14 & 29.8 \\
\hline Discomfort due to injury & 6 & 48.5 & 16 & 34.0 \\
\hline Limited physical activity & 10 & 30.3 & 13 & 27.7 \\
\hline Impaired other functions & 3 & 9.1 & 4 & 8.5 \\
\hline Main injury site & 38 & & 50 & 33.6 \\
\hline Head and neck & 16 & 42.1 & 21 & 42.0 \\
\hline Spine/upper back & 2 & 5.3 & 2 & 4.0 \\
\hline
\end{tabular}

Note *: 3 children with CP did not report relevant information; \#: 5 children with CP did not report relevant information; a: 6 children with $\mathrm{CP}$ did not report relevant information; $\mathrm{b}: 1$ children with $\mathrm{CP}$ did not report relevant information; c:7 children with CP did not report relevant information; $\mathrm{d}$ : 4 children with CP did not report relevant information 


\begin{tabular}{|c|c|c|c|c|}
\hline \multirow[t]{2}{*}{ Injury characteristics } & \multicolumn{2}{|c|}{$\begin{array}{l}\text { Past three } \\
\text { months }\end{array}$} & \multicolumn{2}{|c|}{ Past year } \\
\hline & No & $\%$ & No & $\%$ \\
\hline chest & 0 & 0.0 & 0 & 0.0 \\
\hline abdomen & 0 & 0.0 & 0 & 0.0 \\
\hline Pelvis/lower back & 1 & 2.6 & 1 & 2.0 \\
\hline Buttocks & 2 & 5.3 & 2 & 4.0 \\
\hline Upper limb & 14 & 36.8 & 19 & 38.0 \\
\hline Lower limbs & 17 & 44.7 & 21 & 42.0 \\
\hline Multiple parts & 1 & 2.6 & 2 & 4.0 \\
\hline Unspecified & 0 & 0.00 & 0 & 0.0 \\
\hline Activity & $35^{*}$ & 26.3 & 50 & 33.6 \\
\hline General leisure activities & 20 & 57.1 & 32 & 64.0 \\
\hline movement & 7 & 20.0 & 10 & 20.0 \\
\hline On the way to/from school & 0 & 0 & 0 & 0.0 \\
\hline Cycling on the way to/from school & 0 & 0 & 0 & 0.0 \\
\hline Sleep/rest & 1 & 2.9 & 1 & 2.0 \\
\hline eat & 1 & 2.9 & 1 & 2.0 \\
\hline By car (bus, bus and other motor vehicles, etc.) & 0 & 0 & 0 & 0.0 \\
\hline other & 6 & 17.1 & 6 & 12.0 \\
\hline Are you hospitalized for treatment after the injury? & $35^{*}$ & 26.3 & $49^{b}$ & 32.9 \\
\hline Yes & 21 & 60.0 & 22 & 44.9 \\
\hline no & 14 & 40.0 & 27 & 55.1 \\
\hline How long has the child's daily life been restricted after the injury & $35^{*}$ & 26.3 & $46^{d}$ & 32.2 \\
\hline Not restricted & 5 & 14.7 & 12 & 26.1 \\
\hline Less than 1 day & 6 & 17.6 & 7 & 15.2 \\
\hline
\end{tabular}

Note *: 3 children with CP did not report relevant information; \#: 5 children with CP did not report relevant information; a: 6 children with $\mathrm{CP}$ did not report relevant information; $\mathrm{b}: 1$ children with $\mathrm{CP}$ did not report relevant information; c:7 children with CP did not report relevant information; $\mathrm{d}$ : 4 children with CP did not report relevant information 


\begin{tabular}{|c|c|c|c|c|}
\hline \multirow[t]{2}{*}{ Injury characteristics } & \multicolumn{2}{|c|}{$\begin{array}{l}\text { Past three } \\
\text { months }\end{array}$} & \multicolumn{2}{|c|}{ Past year } \\
\hline & No & $\%$ & No & $\%$ \\
\hline $1-7$ days & 6 & 17.6 & 7 & 15.2 \\
\hline $7-14$ days & 2 & 5.9 & 3 & 6.5 \\
\hline 14 days- 1 month & 6 & 17.6 & 5 & 10.9 \\
\hline$\geq 1$ month & 9 & 26.5 & 12 & 26.1 \\
\hline $\begin{array}{l}\text { How many days did the child not go to kindergarten or school due } \\
\text { to injury }\end{array}$ & $33^{\#}$ & 25.8 & $43^{c}$ & 31.6 \\
\hline 0 days & 14 & 42.4 & 20 & 46.5 \\
\hline Less than 1 day & 1 & 3.0 & 1 & 2.3 \\
\hline $1-5$ days & 4 & 12.1 & 8 & 18.6 \\
\hline$\geq 6$ days & 14 & 42.4 & 14 & 32.6 \\
\hline Source of treatment costs & $35^{\star}$ & 26.3 & $44^{\mathrm{a}}$ & 31.2 \\
\hline Public expense & 1 & 2.9 & 2 & 4.5 \\
\hline Social Basic Medical Insurance & 10 & 29.4 & 13 & 29.5 \\
\hline Own expense & 21 & 61.8 & 27 & 61.4 \\
\hline other & 2 & 5.9 & 2 & 4.5 \\
\hline
\end{tabular}

\subsubsection{Features of unintentional injuries in children with CP in the past one year}

Among 117 children with $C P, 50(42.7 \%)$ had unintentional injuries in the past year:(30/44 68.2\%) had an unintentional injury, and (9/44 20.5\%) had re-injures, 6 cases of children did not report the time of injury. From the point of view of the location and site of injuries, most of them occurred indoors $(30 / 50,60.0 \%)$, and the main injured parts were head and neck $(21 / 50,42.0 \%)$ and lower limbs $(21 / 50,42.0 \%)$; From the point of view of the cause of injury, accidental fall was the main reason $(31 / 50,62.0 \%)$; from the point of view of the severity of injury and the treatment of injury, the injury was mild to moderate (42/50,84.0\%), most of them went to the hospital for treatment or self-treatment (40/50,80.0\%), and nearly half of them were hospitalized for treatment (24/50,48\%); Unintentional injuries of children with CP mainly occur in general leisure activities (32/50,64.0\%) (Table 1). 


\subsection{The influence of different family factors on unintentional injury of children with $\mathrm{CP}$ in the past three months}

This study included gender, age, age of parents, parents' education level, family income, family population, number of children, main caregivers, time spent with parents, children's long-term residence, children's personality, safety education guidance, etc. A single factor analysis of family factors found that the incidence of unintentional injuries in girls with $\mathrm{CP}$ was significantly higher than that in boys, and the difference was statistically significant $(2=6.105, P=0.013)$; The father's education and family income were the risk factors for unintentional accidental injury in children with $C P(P<0.05)$. Children with $C P$ who spend less than 2 hours with their parents had a significantly higher risk of unintentional injury than children with $\mathrm{CP}$ who spend more than 4 hours together $(2=8.076, \mathrm{P}=0.018)($ Table 2$)$. 
Table 2

The influence of different family factors on unintentional injury of children with $\mathrm{CP}$ in the past three months

\begin{tabular}{|c|c|c|c|c|c|}
\hline \multirow{2}{*}{$\begin{array}{l}\text { Variable } \\
\text { characteristics }\end{array}$} & \multirow[t]{2}{*}{ Classification } & \multicolumn{2}{|c|}{ Children with $\mathrm{CP}$} & \multirow{2}{*}{$\begin{array}{l}\chi^{2} \\
\text { value }\end{array}$} & \multirow{2}{*}{$\begin{array}{l}P \\
\text { value }\end{array}$} \\
\hline & & $\begin{array}{l}\text { number of } \\
\text { children }(\mathrm{n}= \\
117)\end{array}$ & $\begin{array}{l}\text { number of } \\
\text { injured }(n= \\
\text { 38) }\end{array}$ & & \\
\hline \multirow[t]{2}{*}{ gender } & male & 74 & $18(24.3)$ & \multirow[t]{2}{*}{6.105} & \multirow[t]{2}{*}{0.013} \\
\hline & Female & 43 & $20(46.5)$ & & \\
\hline \multirow[t]{3}{*}{ age } & $0-4$ & 67 & $22(32.8)$ & \multirow[t]{3}{*}{2.786} & \multirow[t]{3}{*}{0.248} \\
\hline & $5-10$ & 41 & $11(26.8)$ & & \\
\hline & $11-18$ & 9 & $5(55.6)$ & & \\
\hline \multirow[t]{4}{*}{ Father's age } & $<30$ & 20 & $6(30.0)$ & \multirow[t]{4}{*}{0.246} & \multirow[t]{4}{*}{0.970} \\
\hline & $30-34$ & 59 & 19(32.2) & & \\
\hline & $35-39$ & 22 & $7(31.8)$ & & \\
\hline & $>=40$ & 16 & $6(37.5)$ & & \\
\hline \multirow[t]{4}{*}{ Mother's age } & $<30$ & 41 & 19(46.3) & \multirow[t]{4}{*}{7.666} & \multirow[t]{4}{*}{0.053} \\
\hline & $30-34$ & 50 & $10(20.0)$ & & \\
\hline & $35-39$ & 15 & $6(40.0)$ & & \\
\hline & $>=40$ & 11 & $3(27.3)$ & & \\
\hline \multirow[t]{3}{*}{ Family population } & $<3$ & 41 & $15(36.6)$ & \multirow[t]{3}{*}{0.574} & \multirow[t]{3}{*}{0.761} \\
\hline & $4-5$ & 64 & 19(29.7) & & \\
\hline & $>=6$ & 12 & $4(33.3)$ & & \\
\hline \multirow[t]{2}{*}{ Number of children } & $<=1$ & 59 & $20(33.9)$ & \multirow[t]{2}{*}{0.109} & \multirow[t]{2}{*}{0.741} \\
\hline & $>=2$ & 58 & $18(31.0)$ & & \\
\hline \multirow{3}{*}{$\begin{array}{l}\text { The current living } \\
\text { situation of the } \\
\text { child }\end{array}$} & With parents & 61 & $15(24.6)$ & \multirow[t]{3}{*}{3.640} & \multirow[t]{3}{*}{0.162} \\
\hline & With one parent & 25 & $10(40.0)$ & & \\
\hline & With grandparents & 30 & $13(43.3)$ & & \\
\hline \multirow{3}{*}{$\begin{array}{l}\text { Children currently } \\
\text { studying at }\end{array}$} & kindergarten & 16 & $6(37.5)$ & \multirow[t]{3}{*}{1.233} & \multirow[t]{3}{*}{0.745} \\
\hline & primary school & 14 & $5(35.7)$ & & \\
\hline & junior high school & 2 & $0(0)$ & & \\
\hline
\end{tabular}




\begin{tabular}{|c|c|c|c|c|c|}
\hline & Not enrolled & 85 & $27(31.8)$ & & \\
\hline \multirow[t]{4}{*}{ Father's education } & primary school & 5 & $2(40.0)$ & \multirow[t]{4}{*}{5.862} & \multirow[t]{4}{*}{0.019} \\
\hline & junior high school & 38 & 12(31.6) & & \\
\hline & $\begin{array}{l}\text { High school, technical } \\
\text { secondary school }\end{array}$ & 44 & $19(43.2)$ & & \\
\hline & $\begin{array}{l}\text { Bachelor degree and } \\
\text { above }\end{array}$ & 30 & $5(16.7)$ & & \\
\hline \multirow[t]{4}{*}{ Mother's education } & primary school & 6 & $3(50.0)$ & \multirow[t]{4}{*}{5.199} & \multirow[t]{4}{*}{0.158} \\
\hline & junior high school & 37 & 11(29.7) & & \\
\hline & $\begin{array}{l}\text { High school, technical } \\
\text { secondary school }\end{array}$ & 48 & 19(39.6) & & \\
\hline & $\begin{array}{l}\text { Bachelor degree and } \\
\text { above }\end{array}$ & 25 & $4(16.0)$ & & \\
\hline \multirow{3}{*}{$\begin{array}{l}\text { Child's long-term } \\
\text { residence }\end{array}$} & Rural area & 54 & $23(42.6)$ & \multirow[t]{3}{*}{5.327} & \multirow[t]{3}{*}{0.070} \\
\hline & city & 58 & $13(22.4)$ & & \\
\hline & other & 5 & $2(40.0)$ & & \\
\hline \multirow[t]{5}{*}{ Household income } & Below 1000 yuan & 6 & $1(16.7)$ & \multirow[t]{5}{*}{13.508} & \multirow[t]{5}{*}{0.009} \\
\hline & 1000 yuan & 19 & $12(63.2)$ & & \\
\hline & 3000 yuan & 40 & $12(30.0)$ & & \\
\hline & 5000 yuan & 37 & $12(32.4)$ & & \\
\hline & More than 10,000 yuan & 15 & $1(6.7)$ & & \\
\hline \multirow[t]{3}{*}{ Child character } & gentle and quiet & 15 & $6(40.0)$ & \multirow[t]{3}{*}{0.456} & \multirow[t]{3}{*}{0.796} \\
\hline & general & 55 & 17(30.9) & & \\
\hline & active & 47 & 15(31.9) & & \\
\hline \multirow{2}{*}{$\begin{array}{l}\text { Safety education } \\
\text { guidance }\end{array}$} & no & 40 & $17(42.5)$ & \multirow[t]{2}{*}{2.323} & \multirow[t]{2}{*}{0.127} \\
\hline & Yes & 76 & $21(27.6)$ & & \\
\hline \multirow[t]{3}{*}{ Time with parents } & Within 2 hours/day & 13 & $6(46.2)$ & \multirow[t]{3}{*}{8.076} & \multirow[t]{3}{*}{0.018} \\
\hline & 2-4 hours/day & 15 & $9(60.0)$ & & \\
\hline & More than 4 hours & 89 & $23(25.8)$ & & \\
\hline \multirow[t]{2}{*}{ Child care situation } & One parent is full-time & 69 & 19(27.5) & \multirow[t]{2}{*}{5.036} & \multirow[t]{2}{*}{0.169} \\
\hline & $\begin{array}{l}\text { Grandma/grandparents } \\
\text { full-time }\end{array}$ & 42 & $18(42.9)$ & & \\
\hline
\end{tabular}




\begin{tabular}{|lll|} 
full-time nanny & 1 & $0(0)$ \\
\hline Pluralistic nanny & 3 & $0(0)$ \\
\hline No special person & 2 & $1(50.0)$ \\
\hline
\end{tabular}

\subsection{The impact of different environmental factors on unintentional injuries in children with $\mathrm{CP}$ in the past three months}

This study included whether there was a construction site near the residence; whether the residence was close to the road; whether the surrounding environment was steep; whether there was a lake, river or water ditch around; whether the elevator was used to go upstairs; whether there were fireworks at home; whether used a stove for heating in winter; whether the heat source was in a place that is was easy for children to touch; whether the floor in the home was non-slip; whether the indoor light was bright; whether the medicines in the home can be easily obtained; whether the fruit knives, kitchen knives, scissors and other sharp objects in the home could be accessed by children; whether children like toys such as marbles; and whether window guards were installed in the home. The analysis of the impact of 15 environmental factors on the unintentional injury of children with $\mathrm{CP}$ found that the rate of unintentional injuries in children with CP in the steep surroundings of the house $(13 / 27,58.1 \%)$ was significantly higher than that in children with flat surroundings $(25 / 90,27.8 \%)$, and other environmental factors had no effect on unintentional injuries of children with $\mathrm{CP}(\mathrm{P}>0.05)$ (Table 3$)$. 
Table 3

The impact of different environmental factors on unintentional injuries in children with $\mathrm{CP}$ in the past three months

\begin{tabular}{|c|c|c|c|c|c|}
\hline \multirow[t]{2}{*}{ Variable characteristics } & \multirow[t]{2}{*}{ classification } & \multicolumn{2}{|c|}{ Children with $\mathrm{CP}$} & \multirow{2}{*}{$\chi^{2}$} & \multirow{2}{*}{$\begin{array}{l}P \\
\text { value }\end{array}$} \\
\hline & & $\begin{array}{l}\text { Number } \\
\text { of } \\
\text { children(n } \\
=117)\end{array}$ & $\begin{array}{l}\text { number } \\
\text { of } \\
\text { injured(n } \\
=38)\end{array}$ & & \\
\hline \multirow{2}{*}{$\begin{array}{l}\text { With or without construction site } \\
\text { attached to the residence }\end{array}$} & no & 82 & $29(35.4)$ & \multirow[t]{2}{*}{1.042} & \multirow[t]{2}{*}{0.307} \\
\hline & Yes & 35 & $9(25.7)$ & & \\
\hline \multirow[t]{2}{*}{ The residence is close to the road } & no & 51 & 16(31.4) & \multirow[t]{2}{*}{0.050} & \multirow[t]{2}{*}{0.822} \\
\hline & Yes & 66 & 22(33.3) & & \\
\hline \multirow[t]{2}{*}{ The surrounding environment is steep } & no & 90 & $25(27.8)$ & \multirow[t]{2}{*}{3.930} & \multirow[t]{2}{*}{0.047} \\
\hline & Yes & 27 & 13(58.1) & & \\
\hline \multirow[t]{2}{*}{ There are lakes, rivers or ditches } & no & 72 & $20(27.8)$ & \multirow[t]{2}{*}{1.886} & \multirow[t]{2}{*}{0.170} \\
\hline & Yes & 45 & $18(40.0)$ & & \\
\hline \multirow{2}{*}{$\begin{array}{l}\text { Did you use the elevator to go } \\
\text { upstairs? }\end{array}$} & no & 83 & $25(30.1)$ & \multirow[t]{2}{*}{0.724} & \multirow[t]{2}{*}{0.395} \\
\hline & Yes & 34 & 13(38.2) & & \\
\hline \multirow{2}{*}{$\begin{array}{l}\text { There are fireworks and firecracker at } \\
\text { home }\end{array}$} & no & 114 & $36(31.6)$ & \multirow[t]{2}{*}{-} & \multirow[t]{2}{*}{$0.246^{\star}$} \\
\hline & Yes & 3 & $2(66.7)$ & & \\
\hline \multirow[t]{2}{*}{ Whether a brazier is used for heating } & no & 58 & 18(31.0) & \multirow[t]{2}{*}{0.109} & \multirow[t]{2}{*}{0.741} \\
\hline & Yes & 59 & 20(33.9) & & \\
\hline \multirow{2}{*}{$\begin{array}{l}\text { The heat source is in a place that } \\
\text { children can easily touch }\end{array}$} & no & 89 & $26(29.2)$ & \multirow[t]{2}{*}{1.808} & \multirow[t]{2}{*}{0.179} \\
\hline & Yes & 28 & $12(42.9)$ & & \\
\hline \multirow[t]{2}{*}{ Non-slip floors in the home } & no & 54 & 18(33.3) & \multirow[t]{2}{*}{0.033} & \multirow[t]{2}{*}{0.855} \\
\hline & Yes & 63 & $20(31.7)$ & & \\
\hline \multirow[t]{2}{*}{ Bright indoors } & no & 10 & $5(50.0)$ & \multirow[t]{2}{*}{1.531} & 0.216 \\
\hline & Yes & 107 & $33(30.8)$ & & \\
\hline Medicines are easily available & no & 104 & $35(33.7)$ & 0.589 & 0.443 \\
\hline & Yes & 13 & $3(23.1)$ & & \\
\hline $\begin{array}{l}\text { Fruit knives, kitchen knives, scissors } \\
\text { and other sharp tools in the home can }\end{array}$ & no & 100 & $30(30.0)$ & 1.928 & 0.165 \\
\hline
\end{tabular}




\begin{tabular}{|c|c|c|c|c|c|}
\hline \multirow{3}{*}{ Children like toys such as marbles } & Yes & 17 & $8(47.1)$ & & \\
\hline & no & 80 & $24(30.0)$ & \multirow[t]{2}{*}{0.709} & \multirow[t]{2}{*}{0.400} \\
\hline & Yes & 37 & $14(37.8)$ & & \\
\hline \multirow[t]{2}{*}{ Install window guards in your home } & no & 29 & $13(44.8)$ & \multirow[t]{2}{*}{2.681} & \multirow[t]{2}{*}{0.102} \\
\hline & Yes & 88 & $25(28.4)$ & & \\
\hline
\end{tabular}

\subsection{The influence of different family factors on unintentional injuries of children with CP in the past year}

A single factor analysis of family factors found that the incidence of unintentional injuries in children with $\mathrm{CP}$ in the past year was the highest at the age of $11-18$ years $(9 / 9)$, and the older the child, the higher the incidence of unintentional injuries in the past year $(\chi 2=16.225, P<0.001)$. In addition, children with $\mathrm{CP}$ whose family population was greater than or equal to 6 had the highest incidence of unintentional injuries $(9 / 1275.0 \%)(\chi 2=6.336, P=0.042)$.Furthermore, the incidence of unintentional injuries in children with CP who lived with their grandparents in the past year was higher than that of children who lived with their parents and one of their parents $(\chi 2=6.159, P=0.046)$ (Table 4). 
Table 4

The influence of different family factors on unintentional injuries of children with $\mathrm{CP}$ in the past year

\begin{tabular}{|c|c|c|c|c|c|}
\hline \multirow{2}{*}{$\begin{array}{l}\text { Variable } \\
\text { characteristics }\end{array}$} & \multirow[t]{2}{*}{ Classification } & \multicolumn{2}{|c|}{ Children with $\mathrm{CP}$} & \multirow{2}{*}{$\begin{array}{l}\chi^{2} \\
\text { value }\end{array}$} & \multirow{2}{*}{$\begin{array}{l}P \\
\text { value }\end{array}$} \\
\hline & & $\begin{array}{l}\text { number of } \\
\text { children }(n= \\
117)\end{array}$ & $\begin{array}{l}\text { number of } \\
\text { injured }(n= \\
50)\end{array}$ & & \\
\hline \multirow[t]{2}{*}{ gender } & male & 74 & 28(37.8) & \multirow[t]{2}{*}{1.973} & \multirow[t]{2}{*}{0.160} \\
\hline & Female & 43 & $22(51.2)$ & & \\
\hline \multirow[t]{3}{*}{ age } & $0-4$ & 67 & 21(31.3) & \multirow[t]{3}{*}{16.225} & \multirow[t]{3}{*}{0.000} \\
\hline & $5-10$ & 41 & $20(48.8)$ & & \\
\hline & $11-18$ & 9 & $9(100.0)$ & & \\
\hline \multirow[t]{4}{*}{ Father's age } & $<30$ & 20 & $5(25.0)$ & \multirow[t]{4}{*}{3.181} & \multirow[t]{4}{*}{0.364} \\
\hline & $30-34$ & 59 & $28(47.5)$ & & \\
\hline & $35-39$ & 22 & $10(45.5)$ & & \\
\hline & $>=40$ & 16 & $7(43.8)$ & & \\
\hline \multirow[t]{4}{*}{ Mother's age } & $<30$ & 41 & $19(46.3)$ & \multirow[t]{4}{*}{0.804} & \multirow[t]{4}{*}{0.849} \\
\hline & $30-34$ & 50 & 19(38.0) & & \\
\hline & $35-39$ & 15 & $7(56.7)$ & & \\
\hline & $>=40$ & 11 & $5(45.5)$ & & \\
\hline \multirow[t]{3}{*}{ Family population } & $<3$ & 41 & $18(43.9)$ & \multirow[t]{3}{*}{6.336} & \multirow[t]{3}{*}{0.042} \\
\hline & $4-5$ & 64 & $23(35.9)$ & & \\
\hline & $>=6$ & 12 & $9(75.0)$ & & \\
\hline \multirow[t]{2}{*}{ Number of children } & $<=1$ & 59 & $26(44.1)$ & \multirow[t]{2}{*}{0.086} & \multirow[t]{2}{*}{0.769} \\
\hline & $>=2$ & 58 & $24(41.4)$ & & \\
\hline \multirow{3}{*}{$\begin{array}{l}\text { The current living } \\
\text { situation of the } \\
\text { child }\end{array}$} & With parents & 61 & $21(34.4)$ & \multirow[t]{3}{*}{6.159} & \multirow[t]{3}{*}{0.046} \\
\hline & With one parent & 25 & $10(40.0)$ & & \\
\hline & With grandparents & 30 & 19(63.3) & & \\
\hline \multirow{4}{*}{$\begin{array}{l}\text { Children currently } \\
\text { studying at }\end{array}$} & kindergarten & 1 & $1(100.0)$ & \multirow[t]{4}{*}{2.107} & \multirow[t]{4}{*}{0.550} \\
\hline & primary school & 16 & $8(50.0)$ & & \\
\hline & junior high school & 14 & $8(57.1)$ & & \\
\hline & Not enrolled & 2 & $1(50.0)$ & & \\
\hline
\end{tabular}




\begin{tabular}{|c|c|c|c|c|c|}
\hline \multirow[t]{4}{*}{ Father's education } & primary school & 85 & $33(38.8)$ & \multirow[t]{4}{*}{5.694} & \multirow[t]{4}{*}{0.127} \\
\hline & junior high school & 5 & $2(40.0)$ & & \\
\hline & $\begin{array}{l}\text { High school, technical } \\
\text { secondary school }\end{array}$ & 38 & $16(42.1)$ & & \\
\hline & $\begin{array}{l}\text { Bachelor degree and } \\
\text { above }\end{array}$ & 44 & $24(54.5)$ & & \\
\hline \multirow[t]{4}{*}{ Mother's education } & primary school & 30 & $8(26.7)$ & \multirow[t]{4}{*}{3.454} & \multirow[t]{4}{*}{0.327} \\
\hline & junior high school & 6 & $3(50.0)$ & & \\
\hline & $\begin{array}{l}\text { High school, technical } \\
\text { secondary school }\end{array}$ & 37 & $15(40.5)$ & & \\
\hline & $\begin{array}{l}\text { Bachelor degree and } \\
\text { above }\end{array}$ & 48 & $24(50.0)$ & & \\
\hline \multirow{3}{*}{$\begin{array}{l}\text { Child's long-term } \\
\text { residence }\end{array}$} & Rural area & 25 & $7(28.0)$ & \multirow[t]{3}{*}{5.029} & \multirow[t]{3}{*}{0.081} \\
\hline & city & 54 & $29(53.7)$ & & \\
\hline & other & 58 & 19(32.8) & & \\
\hline \multirow[t]{5}{*}{ Household income } & Below 1000 yuan & 5 & $2(40.0)$ & \multirow[t]{5}{*}{8.093} & \multirow[t]{5}{*}{0.088} \\
\hline & 1000 yuan & 6 & $4(66.7)$ & & \\
\hline & 3000 yuan & 19 & $12(63.2)$ & & \\
\hline & 5000 yuan & 40 & $13(32.5)$ & & \\
\hline & More than 10,000 yuan & 37 & $17(45.9)$ & & \\
\hline \multirow[t]{3}{*}{ Child character } & gentle and quiet & 15 & $4(26.7)$ & \multirow[t]{3}{*}{1.227} & \multirow[t]{3}{*}{0.541} \\
\hline & general & 15 & $8(53.3)$ & & \\
\hline & active & 55 & 21(38.2) & & \\
\hline \multirow{2}{*}{$\begin{array}{l}\text { Safety education } \\
\text { guidance }\end{array}$} & no & 47 & $21(44.7)$ & \multirow[t]{2}{*}{0.042} & \multirow[t]{2}{*}{0.838} \\
\hline & Yes & 40 & $17(42.5)$ & & \\
\hline \multirow[t]{3}{*}{ Time with parents } & Within 2 hours/day & 76 & $33(43.4)$ & \multirow[t]{3}{*}{3.230} & \multirow[t]{3}{*}{0.199} \\
\hline & 2-4 hours/day & 13 & $7(53.8)$ & & \\
\hline & More than 4 hours & 15 & $9(60.0)$ & & \\
\hline \multirow[t]{3}{*}{ Child care situation } & One parent is full-time & 89 & $34(38.2)$ & \multirow[t]{3}{*}{2.874} & \multirow[t]{3}{*}{0.411} \\
\hline & $\begin{array}{l}\text { Grandma/grandparents } \\
\text { full-time }\end{array}$ & 69 & 26(37.7) & & \\
\hline & full-time nanny & 42 & $22(52.4)$ & & \\
\hline
\end{tabular}




\begin{tabular}{lll} 
Pluralistic nanny & 1 & $0(0)$ \\
\hline No special person & 3 & $1(33.3)$
\end{tabular}

2.5 The impact of different environmental factors on unintentional injuries in children with CP in the past year

The proportion of children with CP $(11 / 17,64.7 \%)$ who can easily access sharp tools such as fruit knives, kitchen knives, and scissors at home had a significantly higher proportion of unintentional injuries than children who could not access $(39 / 100,39.0 \%)(\chi 2=3.9236, P=0.048)$. Other environmental factors had no effect on unintentional injury of CP children $(P>0.05)$. (Table 5). 
Table 5

The impact of different environmental factors on unintentional injuries in children with $\mathrm{CP}$ in the past year

\begin{tabular}{|c|c|c|c|c|c|}
\hline \multirow[t]{2}{*}{ Variable characteristics } & \multirow[t]{2}{*}{ classification } & \multicolumn{2}{|c|}{ Children with $\mathrm{CP}$} & \multirow{2}{*}{$\begin{array}{l}\chi^{2} \\
\text { value }\end{array}$} & \multirow{2}{*}{$\begin{array}{l}P \\
\text { value }\end{array}$} \\
\hline & & $\begin{array}{l}\text { Number } \\
\text { of } \\
\text { children(n } \\
=117)\end{array}$ & $\begin{array}{l}\text { number } \\
\text { of } \\
\text { injured(n } \\
=50)\end{array}$ & & \\
\hline \multirow{2}{*}{$\begin{array}{l}\text { With or without construction site } \\
\text { attached to the residence }\end{array}$} & no & 82 & $36(43.9)$ & \multirow[t]{2}{*}{0.153} & \multirow[t]{2}{*}{0.696} \\
\hline & Yes & 35 & $14(40.0)$ & & \\
\hline \multirow[t]{2}{*}{ The residence is close to the road } & no & 51 & $21(41.2)$ & \multirow[t]{2}{*}{0.090} & \multirow[t]{2}{*}{0.765} \\
\hline & Yes & 66 & $29(43.9)$ & & \\
\hline \multirow[t]{2}{*}{ The surrounding environment is steep } & no & 90 & $37(41.1)$ & \multirow[t]{2}{*}{0.420} & \multirow[t]{2}{*}{0.517} \\
\hline & Yes & 27 & $13(48.1)$ & & \\
\hline \multirow[t]{2}{*}{ There are lakes, rivers or ditches } & no & 72 & 28(38.9) & \multirow[t]{2}{*}{1.132} & \multirow[t]{2}{*}{0.287} \\
\hline & Yes & 45 & 22(48.9) & & \\
\hline \multirow[t]{2}{*}{ Did you use the elevator to go upstairs? } & no & 83 & $35(42.2)$ & \multirow[t]{2}{*}{0.037} & \multirow[t]{2}{*}{0.847} \\
\hline & Yes & 34 & $15(44.1)$ & & \\
\hline \multirow{2}{*}{$\begin{array}{l}\text { There are fireworks and firecracker at } \\
\text { home }\end{array}$} & no & 114 & $48(42.1)$ & \multirow[t]{2}{*}{0.721} & \multirow[t]{2}{*}{0.396} \\
\hline & Yes & 3 & $2(66.7)$ & & \\
\hline \multirow[t]{2}{*}{ Whether a brazier is used for heating } & no & 58 & $22(37.9)$ & \multirow[t]{2}{*}{1.085} & \multirow[t]{2}{*}{0.298} \\
\hline & Yes & 59 & $28(47.5)$ & & \\
\hline \multirow{2}{*}{$\begin{array}{l}\text { The heat source is in a place that } \\
\text { children can easily touch }\end{array}$} & no & 89 & $34(38.2)$ & \multirow[t]{2}{*}{3.122} & \multirow[t]{2}{*}{0.077} \\
\hline & Yes & 28 & 16(57.1) & & \\
\hline \multirow[t]{2}{*}{ Non-slip floors in the home } & no & 54 & 28(51.9) & \multirow[t]{2}{*}{3.406} & \multirow[t]{2}{*}{0.065} \\
\hline & Yes & 63 & $22(34.9)$ & & \\
\hline \multirow[t]{2}{*}{ Bright indoors } & no & 10 & $5(50.0)$ & 0.236 & 0.627 \\
\hline & Yes & 107 & $45(42.1)$ & & \\
\hline Medicines are easily available & no & 104 & $46(44.2)$ & 0.856 & 0.355 \\
\hline & Yes & 13 & $4(30.8)$ & & \\
\hline Fruit knives, kitchen knives, scissors and & no & 100 & $39(39.0)$ & 3.923 & 0.048 \\
\hline obtained by children & Yes & 17 & 11(64.7) & & \\
\hline
\end{tabular}




\begin{tabular}{|lllllll|} 
Children like toys such as marbles & no & 80 & $34(42.5)$ & 0.006 & 0.940 \\
\cline { 2 - 4 } & Yes & 37 & $16(43.2)$ & & \\
Install window guards in your home & no & 39 & $10(34.5)$ & 1.073 & 0.300 \\
\cline { 2 - 4 } & Yes & 88 & $40(45.5)$ & & \\
\hline
\end{tabular}

\subsection{Logistic regression analysis results of unintentional injury risk factors for children with CP in the past three months and one year}

The results of multivariate logistic regression analysis showed that: after controlling for sociodemographic factors and family environment, the risk of accidental injury among girls and children among children with $\mathrm{CP}$ was four times that of boys. The risk of accidental injury for children with $\mathrm{CP}$ with a family income of $1,000-3,000$ was 32.726 times that of children with CP with a family income of more than 10,000 yuan. The risk of intentional injury in children with CP who spend 2-4 hours with their parents per day was 5.815 times that of children with parents who spend more than 4 hours per day(Table 6). 
Table 6

Logistic regression analysis results of unintentional injury risk factors for children with $\mathrm{CP}$ in the past three months and one year

\begin{tabular}{|c|c|c|c|}
\hline Variable characteristics & Classification & $\begin{array}{l}\text { multivariate logistic } \\
\text { mode IOR( }(95 \% \mathrm{Cl})\end{array}$ & $\begin{array}{l}P \\
\text { value }\end{array}$ \\
\hline \multirow[t]{2}{*}{ gender } & male & $0.249(0.082,0.757)$ & \multirow[t]{2}{*}{0.014} \\
\hline & Female & 1 & \\
\hline \multirow[t]{3}{*}{ age } & $0-4$ & $0.264(0.035,1.962)$ & 0.193 \\
\hline & $5-10$ & $0.133(0.017,1.049)$ & 0.056 \\
\hline & $11-18$ & 1 & \\
\hline \multirow[t]{3}{*}{ Family population } & $<3$ & $4.544(0.650,31.754)$ & 0.127 \\
\hline & $4-5$ & $2.423(0.378,15.521)$ & 0.350 \\
\hline & $>=6$ & 1 & \\
\hline \multirow[t]{4}{*}{ Father's education } & primary school & $0.247(0.011,5.700)$ & 0.382 \\
\hline & junior high school & $0.998(0.211,4.727)$ & 0.998 \\
\hline & $\begin{array}{l}\text { High school, } \\
\text { technical } \\
\text { secondary school }\end{array}$ & $1.894(0.485,7.404)$ & 0.358 \\
\hline & $\begin{array}{l}\text { Bachelor degree } \\
\text { and above }\end{array}$ & 1 & \\
\hline \multirow[t]{5}{*}{ Household income } & Below 1000 yuan & $0.860(0.024,30.257)$ & 0.934 \\
\hline & 1000 yuan & $32.726(2.448,437.584)$ & 0.008 \\
\hline & 3000 yuan & $3.939(0.358,43.39)$ & 0.263 \\
\hline & 5000 yuan & 7.614(0.772,75.108) & 0.082 \\
\hline & $\begin{array}{l}\text { More than } 10,000 \\
\text { yuan }\end{array}$ & 1 & \\
\hline \multirow[t]{3}{*}{ Time with parents } & $\begin{array}{l}\text { Within } 2 \\
\text { hours/day }\end{array}$ & $1.316(0.229,7.568)$ & 0.759 \\
\hline & $2-4$ hours/day & $5.815(1.161,29.123)$ & 0.032 \\
\hline & More than 4 hours & 1 & \\
\hline \multirow[t]{2}{*}{ The surrounding environment is steep } & no & $0.343(0.090,1.309)$ & 0.117 \\
\hline & Yes & 1 & \\
\hline $\begin{array}{l}\text { Fruit knives, kitchen knives, scissors and } \\
\text { other sharp tools in the home can be }\end{array}$ & no & $0.921(0.191,4.427)$ & 0.918 \\
\hline
\end{tabular}

obtained by children 


\begin{tabular}{|llll|}
\hline Variable characteristics & Classification & $\begin{array}{l}\text { multivariate logistic } \\
\text { mode IOR(95\% Cl) }\end{array}$ & $\begin{array}{l}\boldsymbol{P} \\
\text { value }\end{array}$ \\
\hline & Yes & 1 \\
\hline
\end{tabular}

\section{Discussion}

Cerebral Palsy (CP) is the most common developmental disorder leading to lifelong motor deficits, often accompanied by multiple impairments such as intelligence, language, vision and hearing. The incidence of CP in my country was about 1.5\%o 4.14\%o, and there were about 5 million in my country by the end of $2018^{[15,16]}$. In this study, the incidence of once unintentional injuries in children with $\mathrm{CP}$ in the past 3 months was $32.47 \%$, and the incidence of re-injury was $3.4 \%$, which was lower than that of normal or disabled children. In addition, our research also found that the causes of unintentional injuries of children with CP were mainly fall. The injured parts were mainly lower limbs and head and neck. The injuries mainly occurred indoors, and most unintentional injuries occurred when resting, sleeping or relaxing. Multivariate logistic regression analysis of this study found that girls, low family income and less time with their parents were risk factors for unintentional injuries in children with $\mathrm{CP}$.

According to existing studies, the incidence of unintentional injuries among primary and middle school students in China reached up to $49.22 \%$, the number of unintentional injuries per capita reached 1.8 times per year, and the incidence of re-injury was $20.90 \%{ }^{[17]}$. The above data suggest that the incidence of unintentional injury in children with CP was significantly lower than that of normal children in our study. The reason might be that children with CP who need special care for daily life spend most of their time in wheelchairs or beds. In addition, many previous studies have found that children with disabilities had a higher risk of accidental injury than disabled children. Zhu et al. ${ }^{[9]}$ found that the incidence of unintentional injuries in children with disabilities was significantly higher than that of normal children $(15.6 \%$ vs. $10.9 \%, P<0.05)$. Furthermore, a Meta-analysis involving 15 research subjects found that the risk of unintentional injury in children with disabilities was 2.39 times that of healthy children ${ }^{[3]}$. Sherrard et al. ${ }^{[10]}$ took the Australian mentally disabled group as the research object and found that the rate of hospitalization for unintentional injuries among people with intellectual disabilities was twice that of the general population. Peiris-John, R et al. ${ }^{[18]}$ found that the risk of unintentional injury in children with disabilities was 1.53 times that of normal teenagers. The reason might be that children with different types and severity of disabilities had different risks of accidental injury ${ }^{[6,11]}$. Besides, studies had shown that disabled children with epilepsy, communication disorders and mental problems were at greater risk of injury ${ }^{[12,19]}$. However, Maattanen, $L$ et al. ${ }^{[14]}$ conducted a study on 445 children with $C P$ in Finland and found that the risk of unintentional injury in children with $\mathrm{CP}$ was 1.2 times that of children without $\mathrm{CP}$, which was contrary to the results of this study. Meanwhile, he study also found that if the children with CP had any comorbidities (such as epilepsy, mental retardation, language impairment, hearing and vision impairment, etc.) in addition to lifelong movement disorders, the probability to suffer unintentional injuries of them would increase by 0.54 times. However, this study did not distinguish children with CP 
with simple dyskinesia and children with $\mathrm{CP}$ with comorbidities, which led to a different result from Maattanen, $L$ et al.

This study found that the injuring mechanism of children with CP were mainly fall injuries, and the injured parts were mainly the lower limbs and head and neck. Similarly, previous study have shown that children with $\mathrm{CP}$ have a higher risk of traumatic brain injury than children without $\mathrm{CP}^{[14]}$. In addition, Zhu HP et al. ${ }^{[11]}$ found that both disabled and normal children were mainly injured in the head and neck, and the main cause of injuries in was falls. Besides, this study found that the injury sites of children with CP mainly occurred indoors, and most of the unintentional injuries occurred during rest, sleep or leisure, which was similar to Zhu HP's finding. To normal children, Ellsässer $\mathrm{G}^{[20]}$ conducted an injury epidemiological analysis on children under 15 years of age in Delmenhorst, Germany, and found that children under 5 years of age were mainly injured at home and around the home, while accidents of children between 5 and 14 most often occurred in schools, homes, roads or streets. Therefore, this reminds us that when formulating strategies to prevent unintentional injuries, we should formulate the most effective measures to prevent accidental falls ${ }^{[21]}$. At the same time, we need improve the home and school environment to reduce the risk of unintentional injury to children with $\mathrm{CP}^{[22]}$.

This study found that girls with CP were more likely to suffer accidental injuries than boys. Similarly, Maattanen, $L$ et al. ${ }^{[14]}$ found that the risk of unintentional injury in girls with $C P$ was 1.4 times that of girls without CP. However, some studies have shown that boys with CP suffer more dental injuries than girls $^{[23,24]}$. Family status was one of the important factors affecting the incidence of children's accidental injuries. This study found that children with low-income had a significantly higher risk of accidental injuries than children with high-income. Similarly, a Canadian study showed that the risk of unintentional injury for children with poor family financial status was 1.67 times that of children with good family financial status ${ }^{[25]}$. Furthermore, Saunders et al. ${ }^{[26]}$ conducted a survey of 999,951 people aged 0-24 who immigrated to Canada and found that the incidence of unintentional injuries among refugees was 1.20 times (95\% Cl: $1.40,1.62)$ that among non-refugees. This may be related to the poor living environment which leads fewer protective factors and poor supervision and management from family members for the children with CP. In addition, this study found that children with CP who spend less time with their parents had a significantly higher risk of unintentional injuries than children with CP who spend a long time with their parents. Similar to this result, previous studies had shown that children living with grandparents were more prone to accidental injuries ${ }^{[27]}$. However, some studies had shown that the time spent with their parents and whether they live with their parents had no effect on the incidence of accidental injuries in children with $\mathrm{CP}^{[28,29]}$. Children with $\mathrm{CP}$ could not take care of themselves, and most of the time they need guardians or parents to help them complete their daily life. Therefore, when parents were busy with work or spend less time with children due to other reasons, children had to be looked after by nanny or elderly people, which leads to ineffective parental supervision of children, lack of care and safety education for children, and finally lead to a high incidence of accidental injuries ${ }^{[30,31]}$. 
Family environment factors were important risk factors for unintentional injuries to children, especially young children. For example, steep roads around homes, slippery floors, use of open braziers or stoves, and storage of fireworks and firecrackers are common in Chinese families, especially rural families.

These factors had a great impact on the occurrence of child injuries. However, this study found that in addition to whether the road around the home was steep, the location of the fruit knife, scissors and other sharp tools at home has an impact on the unintentional injury of children with $\mathrm{CP}$, other family environment factors has no effect. This might be related to the peculiarities of $\mathrm{CP}$, because these children were lagging behind normal children in completing turning over, sitting alone, crawling, standing on hold, and vocalization, and even some children with high muscle tone had lost the ability to move. However, The multivariate logistic regression analysis of this study did not find any risk factors for the family environment.

This study still had certain limitations. First of all, the children with CP included in this study were hospitalized in the rehabilitation department of our hospital. Relatively speaking, their condition might be more serious, so there was a certain selection deviation. Secondly, this study did not include normal children for case-control studies, and the conclusions obtained were compared with normal children reported in the literature. Its universality and generalization require further case-control studies. Finally, this study did not include the CP subtypes, and did not study the impact of CP complications on the incidence of accidental injuries in children with CP.

\section{Objects And Methods}

\section{Ethics Statement}

The study was approved by the Ethics Committee of Hunan Children's Hospital (IRB No: HCHLL-2018-64). Informed written consent was obtained from the parents or caretakers of each child included in this study. All data collection from participants was fully anonymous. All methods were carried out in accordance with relevant guidelines and regulations.

\subsection{Research object}

117 children with CP admitted to Human Children's Hospital from January 1, 2018 to December 31, 2018 were collected as the research objects. Inclusion criteria: meet the diagnostic criteria of the 2015 Chinese CP Rehabilitation Guidelines; $0-18$ years of age; family members of the child agreed to participate in the investigation and signed informed consent; exclusion criteria: diseases that were more likely to cause unintentional injuries such as epilepsy. There were 74 boys (63.2\%) and 43 girls (36.8\%), with an average age of $4.90 \pm 3.21$ years. The highest proportion of children with CP were spastic type $(44.44 \%, 52 / 117)$ followed by mixed type $(36.8 \%, 43 / 117)$, atheistic type $(5.98 \%, 7 / 117)$, ataxic type $(0.86 \%, 1 / 117)$, or other type of CP $(21.37 \%, 25 / 117)$.

\subsection{Research content}


(1) sociodemographic characteristics: including the child's gender, diagnosis, date of birth, age of parents, education level, family population, number of children, living conditions, learning stage, family economic situation, child's personality, the hours the child spend with their parents etc.

(2) Living environment: outdoor environment:(Q1): whether there was a construction site near the residence, (Q2) $\llbracket$ whether it was close to a road, (Q3) $\llbracket$ whether the surrounding environment was steep, (Q4)』whether there were lakes, rivers or ditches, (Q5)【whether there were elevators, etc. Indoor

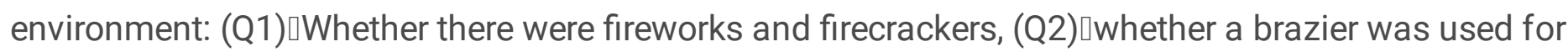
heating,(Q3) $₫$ whether the heat source in the home was in a place that children can easily touch,

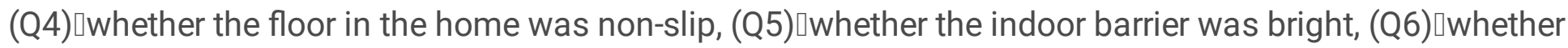
the windows were installed with guardrails, (Q7) $\square$ whether the medicines were easily available, (Q8) whether the fruit knives, kitchen knives, scissors and other sharp tools in the home could be obtained by children.

(3) Characteristics of unintentional injuries : the time, location, cause, severity, treatment after the injury, the result of the injury, the type of injury, and the location of the injury.

\subsection{Related definitions}

An injury case was defined as an incident in a child with CP who had caused medical attention in the past 3 or 12 months. We investigated the number of injured children with $\mathrm{CP}$ and the injury characteristics of each child. We used the main cause of the injury incident to describe the external cause.

\subsection{Quality control}

To ensure the smooth development and the quality of the investigation, we conducted strict quality control on every link involved in the investigation process, including quality control in the design phase, the investigators, the implementation phase, and the data collation and analysis process .

\subsection{Statistical methods}

Statistical analysis: we used SPSS26.0, EXCEL2010 and other software to logically sorted, analyzed and plotted the data, used frequency ( $n$ ) and percentage (\%) to describe the data. After the data was entered into the software, the data was processed through counting and comparison, and the chi-square test of the $\mathrm{R} \times \mathrm{C}$ list or Fisher's exact probability method and Logistic regression were used for data analysis. Firstly, we described the injury characteristics of children with CP, including injury time, cause, type, injured body part, injury location and activities at the time, etc. Secondly, we used the chi-square test to evaluate the influence of the existence of social demographic variables and environmental variables on the risk of accidental injury in children with $\mathrm{CP}$ in the past three months and one year. Finally, logistic regression model was used to assess the injury risk for sampled children by sociodemographic characteristics and home environment factors in multivariate model. In all analyses, a difference of $\mathrm{P}<0.05$ from the significance test was considered statistically significant.

\section{Declarations}


Acknowledgements

The authors are indebted to all the patients who volunteered to participate in this study. We are also grateful to Fatch Kalembo for help with language editing. We also appreciate the support of the data collectors.

\section{Authors' contributors}

QJ WKW and conceived and designed the study. QJ and WKW performed the experiments. QJ and LLJ analyzed the data. HNF LL and GSZ contributed reagents/materials/analysis tools. LLJ wrote the manuscript.

\section{Additional information}

Competing financial interests: The authors declare no competing financial interests.

\section{References}

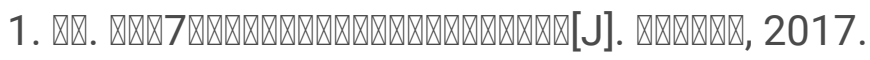

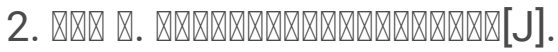

3. Shi, X. et al. Unintentional injuries in children with disabilities: a systematic review and metaanalysis[J]. Injury epidemiology. 2 (1), 21 (2015).

4. Downs, J. et al. The prevalence of mental health disorders and symptoms in children and adolescents with cerebral palsy: a systematic review and meta-analysis[J]. Developmental medicine and child neurology. 60 (1), 30-38 (2018).

5. Yan, S. \& Zhu, X. Epidemiological study on the trend of accidental deaths among children under five in Beijing, during 2003-2012][J]. Zhonghua liu xing bing xue za zhi = Zhonghua liuxingbingxue zazhi, 2014, 35(5):562-565.

6. Zhu, H. et al. Unintentional injuries among Chinese children with different types and severity of disability[J]. Annals of epidemiology. 24 (1), 23-28 (2014).

7. Newacheck, P. \& Halfon, N. Prevalence and impact of disabling chronic conditions in childhood[J]. American journal of public health. 88 (4), 610-617 (1998).

8. Halfon, N. \& Hochstein, M. Life course health development: an integrated framework for developing health, policy, and research[J]. The Milbank quarterly, 2002, 80(3): 433-479, iii.

9. Zhu, H. et al. Deliberate Self-Harm Among Chinese Children with Different Types and Severity of Disabilities[J].International journal of environmental research and public health, 2019, 16(17).

10. Sherrard, J., Tonge, B. \& Ozanne-Smith, J. Injury in young people with intellectual disability: descriptive epidemiology[J]. Injury prevention: journal of the International Society for Child and Adolescent Injury Prevention. 7 (1), 56-61 (2001). 
11. Zhu, H. et al. Disability, home physical environment and non-fatal injuries among young children in China[J]. PLoS One. 7 (5), e37766 (2012).

12. Rowe, R., Maughan, B. \& Goodman, R. Childhood psychiatric disorder and unintentional injury: findings from a national cohort study[J]. Journal of pediatric psychology. 29 (2), 119-130 (2004).

13. Xiang, H. et al. Nonfatal injuries among US children with disabling conditions[J]. American journal of public health. 95 (11), 1970-1975 (2005).

14. Maattanen, L. et al. Risk of hospital-treated injury in children with cerebral palsy: a population-based cohort study[J]. Inj Prev. 26 (4), 310-314 (2020).

15. Salavati, M. et al. Mastery Motivation in Children with Cerebral Palsy (CP) Based on Parental Report: Validity and Reliability of Dimensions of Mastery Questionnaire in Persian[J]. Materia socio-medica. 30 (2), 108-112 (2018).

16. Forni, R. et al. Epidemiology of Cerebral Palsy in Northeastern Switzerland[J]. Pediatric physical therapy: the official publication of the Section on Pediatrics of the American Physical Therapy Association. 30 (2), 155-160 (2018).

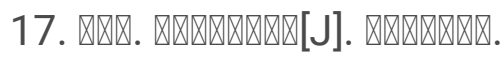

18. Peiris-John, R. et al. Adolescents with disability report higher rates of injury but lower rates of receiving care: findings from a national school-based survey in New Zealand[J]. Injury prevention: journal of the International Society for Child and Adolescent Injury Prevention. 22 (1), 40-45 (2016).

19. Sherrard, J., Tonge, B. \& Ozanne-Smith, J. Injury risk in young people with intellectual disability[J]. Journal of intellectual disability research: JIDR. 46, 6-16 (2002).

20. Ellsasser, G. [Epidemiological Analysis of Injuries Among Children under 15 Years of Age in Germany-The Starting Point for Injury Prevention][J]. Gesundheitswesen. 68 (7), 421-428 (2006).

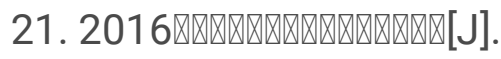

22. United Nations Children's Fund (UNICEF). The state of the world's children:children with disabilities[J].

23. Holan, G. et al. Traumatic injuries to the teeth in young individuals with cerebral palsy[J]216569(official publication of International Association for Dental Traumatology, Dental traumatology, 2005). 2

24. Jalihal, S. et al. Assessment of dental trauma among cerebral palsy individuals in Udaipur city[J] 28448-451(official publication of International Association for Dental Traumatology, Dental traumatology, 2012). 6

25. Kaplan, G., Fraimovich, M. \& Sikron, F. Adolescent health status: new immigrants from the former Soviet Union and Israeli-born][J]. Harefuah. 146 (6), 420-424503 (2007).

26. Saunders, N. et al. Unintentional injuries among refugee and immigrant children and youth in Ontario, Canada: a population-based cross-sectional study[J]. Injury prevention: journal of the International Society for Child and Adolescent Injury Prevention. 24 (5), 337-343 (2018).

27. Delgado, J., Ramirez-Cardich, M. E. \& Gilman, R. H. Risk factors for burns in children: crowding, poverty, and poor maternal education[J]. Inj Prev. 8 (1), 38-41 (2002). 
28. Reading, R. et al. Accidents to preschool children: comparing family and neighbourhood risk factors[J]. Social science \& medicine(1982), 1999, 48(3): 321-330.

29. Wadsworth, J. et al. Family type and accidents in preschool children[J]. Journal of epidemiology and community health. 37 (2), 100-104 (1983).

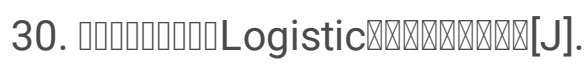

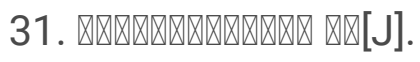

